\title{
SPECIFICITY OF UNDERSTANDING THE PROBLEM OF GENDER RELATIONS IN JHUMPA LAHIRIS WRITING
}

\author{
Yalovenko Olha \\ $\mathrm{PhD}$ in Philology, Senior Lecturer \\ ORCID ID 0000-0001-8787-7339 \\ Pavlo Tychyna Uman State Pedagogical University \\ 2, Sadova St., Uman, 20300, Ukraine \\ olha.yalovenko@ukr.net
}

The article deals with the specificity of understanding the problem of gender relations in Jhumpa Lahiri's writing (the American writer of Bengali origin). The article's aim is to explore the peculiarities of gender relations in the context of the transculture paradigm in Jhumpa Lahiri`s writing. Research methods: historical and typological (determining the specifics of themes, motifs, images, story features of the writer`s works), hermeneutic (interpretation of various aspects of the literary text), narratological analysis (specifics' analysis of J. Lahiri's narrative manner).

It is indicated that the study of gender issues is important in the modern literature discourse. The differences between the adaptation of men and women to the new cultural environment are clearly seen in Jhumpa Lahiri's writing. Yes, men's purpose is to realize their "American dream", as most of them emigrate in search of a better life, scientific and academic goals (an example is the man from the story "Mrs. Sen 's"). Like Bengali families, men have every right to make all the important decisions in the family. The features of Indian women's adaptation to the new culture, which are seen not only in overcoming the language barrier, but are traced in everyday life and in relations with men, are analyzed.

Women have completely different adaptation experiences. The problem of gender relations is traced to the identity crisis of the Indian woman in America, who balances between cultures and lives in two worlds: wants to be American and at the same time not forget her "desh" (literally "homeland" in Bengali).

A stereotyped image of an Indian woman who "sacrifices" herself and remains in despair within the American apartment's walls is portrayed in Jhumpa Lahiri's works. Gender specificity is seen in the role of "invisible existence": heroines are associated with maids who can cook dinner and wash socks only. Women seek refuge in the past and avoid the present.

Unlike men, the assimilation process is much more difficult for women. It is mentioned that J. Lahiri shows the material dependence of women on men. The problem of gender relations that is also associated with the decline of family values, where marriage becomes a temporary matter, is no less important. «other».

Keywords: gender, assimilation, identity, immigrant, transculture, tradition, «our»,

\section{СПЕЦИФІКА ОСМИСЛЕННЯ ПРОБЛЕМИ ГЕНДЕРНИХ СТОСУНКІВ У ТВОРЧОСТІ ДЖУМПИ ЛАГІРІ}

\section{Яловенко Ольга}

к. філол. н., ст. викладач

ORCID ID 0000-0001-8787-7339

Уманський державний педагогічний університет імені Павла Тичини

вул. Садова, 2, м. Умань, 20300, Україна

olha.yalovenko@ukr.net

(C) Yalovenko O., 2020 
У статті аналізується специифіка осмислення проблеми гендерних стосунків у творчості американської письменниці бенгальського походження Д. Лагірі. Мета статті - дослідити особливості тендерних стосунків в контексті транскультурної парадигми у творчочті Джумпи Лагірі. Методи дослідження: історико-типологічний (визначення специифіки тем, мотивів, образів, сюжетних особливостей творів письменниці), герменевтичний (інтерпретація різних аспектів літературного тексту), наратологічний аналіз (аналіз специфіки оповідної манери Д. Лагірі).

Зазначено, щьо дослідження тендерної проблематики важливе у сучасному дискурсі літературознавства. У творчості Д. Лагірі простежуються відмінності адаптації чоловіків та жінок до нового культурного середовища. Так, мета чоловіків - реалізувати свою «американську мрію», оскільки більшість з них емігрують у пошуку крамуого життя, наукових та академічних ичілей (прикладом є чоловік з оповідання «У пані Сен»). Як і належить бенгальським родинам, чоловіки мають повне право приймати всі важливі у родині рішення. Аналізуються особливості адаптаціі індійських жінок до нової культури, які вбачаються не лише в подоланні мовного бар'єру, а помітні в побуті та в стосунках з чоловіками.

Жінки мають зовсім інший досвід адаптаиї. Проблема гендерних стосунків простежується в кризі ідентичності індійської жінки в Америиі, яка балансує між культурами і живе одночасно в двох світах: прагне бути американкою $і$ в той же час не забувати про свою «деш» (дослівно «батьківщина» з бенгальської).

У творах Д. Лагірі змальовується стереотипний образ індійської жінки, яка «жертвує» собою $i$ залишається в безвиходi в стінах американської квартири. Гендерна специфіка розглядається в ролі «невидимого існування»: героїні асоиіюються із служницями, які вміють лише готувати обід та прати икарпетки. Жінки знаходять притулок у минулому та уникають теперішнього.

На відміну від чоловіків, для жінок процес асиміляції набагато важчий. У статті зазначено, щзо Д. Лагірі показує матеріальну залежність жінок від чоловіків. Не менш важливо, щзо проблема тендерних стосунків пов'язується також із занепадом сімейних иінностей, де шлюб перетворюється на тимчасову справу.

Ключові слова: тендер, асиміляція, ідентичність, іммігрант, транскультура, традиція, «своє», «чуже».

\section{Вступ}

Сучасний стан розвитку літературознавства зумовлено тим, що наука про літературу помітно розширила обрії як філологічного, так і соціогуманітарного знання. Дедалі складнішою стає відповідь на питання «Чи $є$ межі у літературознавства?», адже сучасне літературознавство інтегроване в інтердисциплінарний дискурс. Наука про літературу $\epsilon$ водночас i наукою про мистецтво, психологію, історію, культуру, політику тощо.

Література будь-якого народу має свою традицію зображення жінки. Образ жінки обумовлено характером самої культури, адже вагому роль тут відіграють етнічні традиції, символи, фольклорні, міфологічні та прецедентні феномени. С. Єфремов у цьому контексті зауважує, що саме через жіночі образи «найкраще можна пізнати національну вдачу, національний дух, саму навіть національну ідею кожного народу. Адже завжди і всюди жінка творила й охороняла домашнє вогнище, під iї доглядом та піклуванням були усі «хатні справи», отже й традиції роду, а значить і самої породи певного грунту людей. Саме в жіночих постатях знаходять своє втілення найтиповіші вияви національного духу, найглибші його ознаки та разом і ті загальні змагання, які хвилюють почуття» (Єфремов, 1995: 334-335).

Жіночий образ, на думку М. Кудрявцева, відіграє у творі велику роль «як суб'єкт нації у виборі моральних орієнтирів, сенсу життя, ідеалів, що визначають злет чи падіння, самоствердження чи деградацію, людяність чи бездуховність, прогрес чи стагнацію» (Кудрявцев, 2007: 289). 
Мета статті - дослідити особливості гендерних стосунків в контексті транскультурної парадигми у творчочті Джумпи Лагірі.

\section{Матеріали та методи дослідження}

Аналіз статті здійснено на матеріалі творчості американської письменниці бенгальського походження Джумпи Лагірі. До уваги взято окремі твори письменниці, а саме: оповідання «У пані Сен» (“Mrs. Sen`s”), «Не ваша справа» (“Nobody`s Business"), «Тлумач хвороб» (“Interpreter of maladies”), роман «Тезка» (“The Namesake”).

В ході аналізу проблеми використано такі методи дослідження: історикотипологічний (визначення специфіки тем, мотивів, образів, сюжетних особливостей творів письменниці), герменевтичний (інтерпретація різних аспектів літературного тексту), наратологічний аналіз (аналіз специфіки оповідної манери Д. Лагірі).

\section{Обговорення}

Гендерні дослідження не втрачають своєї актуальності в сучасній науці. До прикладу візьмемо збірник праць «Жінки на краю Європи» (Балей, 2002), де порушується проблема жіночого досвіду. Науковці О. Дедок, Г. Дербіна, Л. Любомирськи, Р. Ратчілд, Д. Ренсел, М. Рютес, Л. Старцева, В. Шиманець та ін. проводять аналіз гендерних відносин, піднімають питання ролі жінки у різні історичні періоди на території Західної Свропи.

Проблему гендеру у творчості Д. Лагірі досліджують Т. Arianto (Indoctrination Against Women in "The Lowland" by Jhumpa Lahiri), S. Chattopadhyay (Crossing Border in search of "Home": Gender and Empowerment in Jhumpa Lahiri”s "The Namesake"), S. Dar (The Portrayal of Women as Rebels in the Literary Works of Jhumpa Lahiri and Bharati Mukherjee), S. Mehta (Exploring Gender in the Literature of the Indian Diaspora), E. Vojdani and V. Rahiminezhad (Gender and Social Issues in Persian translation: A Case Study of Jhumpa Lahiri`s "The Namesake"), D. Shanmugam (Portrayal of Indian Women in Jhumpa Lahiri`s "Unaccustomed Earth”) та інші.

\section{Виклад основного матеріалу}

Жіноче питання піднімається багатьма письменниками. Не є виключенням і Д. Лагірі, у творчості якої простежуються відмінності адаптації чоловіків та жінок до нового культурного середовища. Так, мета чоловіків - реалізувати свою «американську мрію», оскільки більшість 3 них емігрують у пошуку кращого життя, наукових та академічних цілей (прикладом є чоловік 3 оповідання «У пані Сен»). Як і належить бенгальським родинам, чоловіки мають повне право приймати всі важливі у родині рішення.

Досвід адаптації в оповіданні «У пані Сен». Жінки мають зовсім інший досвід адаптації. А. Генлі зауважує, що «письменниці часто представляють втрату місця як перший крок жінки до самоствердження» (Henley, 1992: 82). Дотримуючись культу родини, вони (жінки) емігрують за чоловіком і, як результат, замкнені в просторі «чужих» квартир. Цікаву думку в цьому плані висловив Дж. Кліфорд, зауважуючи, що «гарна подорож» (героїчна, освітня, наукова, пригодницька, лицарська) личить чоловікам. Жінок утримують від серйозних поїздок. А якщо вони їдуть до далеких країн, то в основному для компанії або, як виняток, [вони] змушені приймати, наслідувати або таємно протестувати проти правил та досвіду, які належать чоловікам» (Clifford, 1997: 32). Це, власне, і робить пані Сен (головна героїня оповідання «У пані Сен»); вона їде за чоловіком до чужої Америки і усвідомлює, що іiї «привезли» сюди як річ. Для пані Сен життя в Америці дуже відрізняється від життя в Калькутті.

Образ жінки письменниця показує, в основному, крізь внутрішньо самотніх, скривджених і нещасних жінок, які позбавлені змоги виявити себе як особистість (крім сфери сім’і), але «саме це обмеження в тематичних можливостях розробки жіночих образів призвело до заглиблення в її внутрішній світ» (Матіос, 2005: 17). 
Назва оповідання «У пані Сен» (“Mrs. Sen`s”) означає будинок, місце, де знаходиться головна героїня. Це жінка, яка неохоче поїхала за чоловіком до нової країни, і тепер не в змозі почуватися як вдома. Оповідання показує нездатність пані Сен асимілюватися до американського способу життя, який обрав іiі чоловік. Лише пристрасть героїні до свіжої риби, продукту, який втілює в собі «інше» минуле, яке вона втратила - це спроба зберегти індійське життя, хоча і американську рибу героїня не сприймає (це не та риба, до якої вона звикла в Індії).

Важливою в оповіданні є тема спілкування. Твір змальовує дружбу між двома різними за віком та походженням людьми. Образи головних героїв дуже схожі. I пані Сен, і Еліот позбавлені повноцінного спілкування 3 рідними. Зайнятий роботою, чоловік пані Сен не помічає суму в очах дружини. Тільки Еліот бачить їі внутрішній стан, але допомогти нічим не може. Чоловік не переймається проблемами дружини, він гадає, що зручна американська квартира не дасть їй змоги нудьгувати. Навіть після аварії чоловік «закривається» від дружини, і пояснює матері Еліота, що вона спить, хоча насправді пані Сен плаче.

С. Радж зауважує, що «жага до навчання кермувати автомобілем спрямована не на досягнення свободи пересування незалежно від їі вічно зайнятого чоловіка, а $\epsilon$ відображенням культурної пропаганди Бенгалії, де дружина повинна бути хорошою домогосподаркою, готувати і ретельно вибирати рибу» (Raj, 2016: 465).

В оповіданні показано стереотипний образ індійської жінки, яка «жертвує» собою і залишається в безвиході в стінах американської квартири. Героїня загнана в глухий кут своєї, але насправді чужої квартири. Вона ніколи не думала, що буде так далеко від дому. Пані Сен розуміє, що всі, окрім неї, прагнули, щоб вона «примирилась» 3 американською дійсністю: їі чоловік, який хотів, щоб вона навчилася кермувати, поліцейський, який не арештував їі і не просив заплатити штраф за аварію, продавці рибного магазину, які завжди залишали для неї замовлення. Все залежало тільки від зусиль та бажання пані Сен.

М. Тлостанова переконана, що «специфіка множинної, змінної, динамічної та нерівної собі ідентичності сучасної людини яскраво проявилась в рамках концепції транскультурації» (Тлостанова, 2010: 1). Саме транскультурна ідентичність якнайповніше виражає порубіжну суб'єктність пані Сен. Героїня постає сплавом/сумішшю двох культур і як результат, позбавляється цілісності. Культурна «плутанина» щоразу «повертає» іiі назад до вихідної точки і в той же час витворює новий імагологічний образ iі ідентичності. Рішення пані Сен водити автомобіль означає ऑii прагнення до незалежності та певною мірою прийняття американських реалій, а отже, прийняття «часткової або другорядної етнічності» (Пискун, 2001: 17). Героїня розуміє, що для того, щоб «вижити» в новій культурі, ій потрібно «відпустити» минуле. Перші спроби перетину культурного кордону безуспішні. Пані Сен, яка не відчуває себе ні азійкою, ні американкою стовідсотково і свідомо приймає роль культурного посередника, обирає автомобіль, який спочатку викликав у неї велике почуття страху, багато в чому пов'язаного з умовною «зустріччю» своєї рідної та нової незнайомої культури.

М. Трінг наголошує, що «якщо жінку не змушує покинути домівку економічна скрута, іiі мобільність обмежена. Транскультурне, специфічно класове та гендерне пересування було протягом століть майже недоступним для жінок, тому кожна жінка, яка подорожувала, ставала вигнанцем для своєї родини, товариства, статі» (Trinh, 1994: 15). Пані Сен приймає реалії нового життя, але досі самотня: вона усвідомлює, що вороття додому вже немає, як і немає справжніх друзів, а чоловік постійно зайнятий на роботі.

Героїня пристосовується до американського побуту і водночас «тримається» за свою культуру та домашні цінності. Вона знаходить притулок у минулому і уникає теперішнього. Характеризуючи героїв збірки, С. Радж зазначає: «фізично вони в Америці, але подумки в Південній Азії. Вони мають справу 3 самотністю та дислокацією, культурним переміщенням, почуттям ідентичності і приналежністю до 
індійської та американської культур з урахуванням дрібних деталей» (Raj, 2016: 460). Образ пані Сен у цьому плані не є виключенням. Героїня порівнює дві культури і постійно розповідає історії свого життя. Говорячи вдома, вона має на увазі там, в Індії, а не в Америці, де вона перебуває на даний момент: “At home, you know, we have a driver; Everything is there” («Ви знаєте, вдома у нас є водій. Все там») (переклад автора статті) (Lahiri, 1999: 125, 126).

Еволюція жіночого образу в оповіданні «Не ваща справа». Проблема гендерних стосунків у творчості Д. Лагірі пов'язується також із безвідповідальністю батьків, труднощами у вихованні дітей, занепадом сімейних цінностей, де шлюб перетворюється на тимчасову справу, і ототожнюється з нудьгою.

В той же час жіночий образ поступово еволюціонує і з'являється новий образ жінки, яка прагне незалежності та свободи. Героїні не хочуть пов'язувати себе виключно сімейними справами (бути турботливими матерями та дружинами, які звикли слухняно підкорятися чоловікові). Вони не бажають проводити на кухні більшу частину дня, натомість віддають перевагу нашвидкуруч приготованим напівфабрикатам; не хочуть стояти у чоловіка за спиною, немов служниця, і чекати доки він поїсть, а вже потім поїсти самій (цього вимагають бенгальські традиціі).

Натомість жінки вказують на рівні права (а інколи навіть і на переваги) порівняно з чоловіками. Це, наприклад, простежується в оповіданні «Не ваша справа», де Санг, головна героїня, руйнує батьківські стереотипи про заміжжя й у свої тридцять років не замислюється про створення сім'ї; ходить на побачення задля розваги. Героїня не «повертається» до своїх коренів, а продовжує жити «вільним» американським життям. Санг не соромиться залишатися у свого хлопця на ніч, чого взагалі не схвалює індійська громада, як і не схвалює незаміжніх жінок. Героїня постає антистереотипом бенгальської жінки, що у свої тридцять живе під гаслом «кохання не існує». Такий образ «нової жінки» (Санг) характеризується простотою в побуті (чайні пакетики на відміну від традиційного індійського чаю, замовлення їжі через Інтернет), повсякденність та зручність в одязі (джинси, кросівки, шорти).

Іендерна специфіка оповідання «Тлумач хвороб». Проблема шлюбних відносин порушується в оповіданні «Тлумач хвороб». 3 самого початку оповідання подружжя Дасів, немов малі діти, сперечаються між собою, кому відвести дитину до туалету. Батьки поводять себе як старші діти, яким на деякий час доручили наглядати за молодшими. По-американськи поводить себе Тіна, коли починає скаржитися вже через п’ять хвилин після того, як містер Капасі забирає їх біля готелю.

У сімейному житті Дасів помітна символічна «тріщина», адже кожен живе своїм, вільним американським життям. Подружжя Дасів не спілкується не через мовний бар'єр - вони «сховалися» за журналом (місіс Дас) та путівником (містер Дас). Усі спроби спілкування один з одним приречені від початку: Даси не довіряють один одному.

Героїня ліниво перегортає бомбейський кіножурнал і не звертає уваги на дітей, які сидять по обидва боки від неї і жують яскраво-зелену жуйку. Дас усвідомлює, що не справляється зі своїми дітьми, тому відчуває ізольованість. Героїня не бачить себе домогосподаркою, іï апатія та байдужість «утворюють» величезну сімейну прірву. У результаті героїня зраджує чоловікові з його товаришем, який одного разу приходить до них у гості. Свою зраду місіс Дас пов'язує із «симптомом Америки». Вона розуміє, що моральні норми в Індії дуже відрізняються від американських. Дас усвідомлює, що не сприймає зраду всерйоз, чим «руйнує» індійські погляди на поняття «родина».

Образ жінки в романі «Тезка». У жанрі великої прози (в романі) Д. Лагірі показує матеріальну залежність жінок від чоловіків, що унеможливлює їх професійну самореалізацію та створює труднощі у їх соціалізації. Жінкам зазвичай адаптуватися важче, оскільки будучи повністю залежними від чоловіків, вони сидять вдома, ізольовані від американської дійсності. У результаті, жінки відчувають глибоку внутрішню травму. Вони думають про дім та про можливість повернення, оскільки 
переконані, що перебувають в Америці тимчасово. Насправді, дім існує тільки в пам'яті та на фотографіях, що з часом також втрачає свою актуальність.

Коли Ашима, героїня роману «Тезка», залишається з сином сама в досі чужому для неї американському будинку, то плаче. Демонструється необхідність подолання психологічного бар'єру: Ашима проживає з чоловіком в облаштованій квартирі, виховує двох дітей, проте дуже сумує за «своїми стінами». Як і належить справжній бенгальській жінці, Ашима ніколи не називає чоловіка по імені, для неї це табу (ім'я свого чоловіка вона дізналася лише після заручин). Навіть після смерті чоловіка вона каже «мій чоловік», а не «мій Ашок».

Майже у всіх творах письменниці традиційні індійські шлюби за домовленістю передують міграції (жінки їдуть до нової країни вже одруженими). Роман «Тезка»не є виключенням, адже вже на перших сторінках твору автор дає докладний опис асиміляції вагітної Ашими, покірної доньки і дружини.

Часто героїні Д. Лагірі привозять традиційні гендерні ідеології Індії, де сім'я має надзвичайно важливе значення. Так відбувається і з Ашимою, коли вона переїжджає 3 чоловіком до Америки, і намагається створити свою традиційну сім'ю. Героїня зіштовхується 3 сильним культурним тиском, який виникає через позицію залежних жінок у діаспорі. Незважаючи на особисті внутрішні конфлікти, героїня докладає чимало зусиль (певним чином порушуючи гендерні стереотипи) аби пристосуватися до американської дійсності.

Життєве призначення жінки полягає у приготуванні страв, у веденні домашнього господарства та у створенні сімейного затишку. Це яскраво демонструє Ашима, адже більшу частину дня героїня проводить на кухні. На відміну від американських жінок, вона особливо ретельно ставиться до процесу приготування їжі, адже це не просте втамування голоду напівфабрикатами. Саме на кухні найбільш простежується гендерна роль жінки (потрібні години копіткої праці для приготування традиційних індійських страв, ретельність та уважність при додаванні приправ, важлива манера споживання їжі).

Ашима свідомо підкреслює індійські деталі свого вбрання: ходить у сарі та наносить червону фарбу на проборі волосся. Незалежно від покоління, сарі стає яскравим проявом того як сприймає себе жінка в контексті іммігрантської, ідентичної та гендерної політики. На відміну від Санг («Не ваша справа») та місіс Дас («Тлумач хвороб»), Ашима не носить коротких спідниць, адже вважає це непристойністю, має довге волосся, не дозволяє собі вживати алкоголь, не поділяє звичку американських жінок кермувати автомобілем, дивується, що на кухні, де вона проводить більшу частину дня, немає фіранок. Незважаючи на тривалий час проживання в Америці, Ашима подумки там, в Індії, тому намагається «одомашнити» звичний американський побут.

\section{Висновки та перспективи}

У художній літературі образу жінки відведено вагоме місце. Образ жінки має культурне коріння та виявляє особливості ментальності бенгальської культури; він $є$ суттєвим чинником пізнання соціокультурних особливостей індійської нації. Художня література не тільки допомагає проникнути в національну, психологічну, загальнолюдську суть жіночих образів, вони самі по собі важливі: без них не можна показати історію, культуру, суспільні відносини, а також побутові проблеми звичайної «маленької» людини. У багатьох творах Д. Лагірі звертається до жіночого образу. Риси, які характеризують жіночі образи саме в індійській літературі - це вірність, турботливість матері та дружини.

У творчості Д. Лагірі образ жінки зазнає еволюції: від обездоленої іммігрантки, яка у всьому підкоряється долі і своєму чоловікові - до духовно розкріпаченої жінки, незалежної, вільної американки, яка обстоює рівні з чоловіком права (як економічні, так і моральні). На противагу сентиментальним героїням, з'являються нові, які 
наповнені новим змістом. Нові героїні повністю руйнують традиційні поняття / уявлення про роль та місце індійської жінки в суспільстві та в родині.

Завдяки літературному переосмисленню жіночих образів у підсвідомості читача формуються асоціації цих образів 3 юністю, коханням, безтурботністю, свободою (образ «нової жінки»), і водночас $з$ печаллю, самотністю, відчаєм та апатією (образ традиційної індійської жінки).

Гендерна специфіка простежується через роль «невидимого існування»: героїні асоціюються із служницями, які вміють лише готувати обід та прати шкарпетки. Не маючи можливості вибору та самореалізації, більшість героїнь так і залишаються самотніми в досі чужих для них американських квартирах.

Незважаючи на символічну «втечу» до нового культурного середовища, образи жінок позбавлені внутрішньої свободи, оскільки «випадають» із звичного культурного середовища. Героїні опиняються в лабіринті химерного світу (у так званій «культурній химерності» перебуває пані Сен та Ашима), сповненого «культурної плутанини». В композиційному плані відбувається «згущення» культурно-просторових координат, що характерно для транскультурної поетики творів письменниці.

Жінки спілкуються тільки бенгальською, ніяковіють, коли зустрічаються поглядом з чоловіком (для індійської жінки неприпустимо дивитися чоловікові в очі). Вони відчувають не лише моральний, але і внутрішній дискомфорт, символічний «незбіг» індійської та американської культур, у результаті чого відбувається конфлікт внутрішньої свідомості з реаліями американської сучасності.

Автор демонструє різні ролі жінки: дочка, сестра, дружина, мати, бабуся, свекруха, невістка, коханка тощо. Жіночі персонажі Д. Лагірі носять як традиційний, так і сучасний характер. Традиційні жіночі персонажі $є$ представниками першого покоління, тоді як сучасні / «нові жінки» належать до другого покоління. Жінкигероїні першого покоління покірні, стримані, лагідні і тихі. Вони у буквальному значенні «прив'язані» до своєї родини, культурних традицій, предметів домашнього вжитку (яскравим підтвердженням цього є Ашима та пані Сен). Натомість жінки другого покоління більш сміливі, автономні, впевнені в собі та незалежні.

Твори Д. Лагірі показують не лише жіночу боротьбу в умовах імміграції. Насамперед, це конструктивна спроба переосмислення самості жінки в сучасному глобалізованому світі. Жіночі персонажі Д. Лагірі усвідомлюють необхідність зміни способу життя, проте дуже часто особисті бажання поступаються традиційним нормам.

Звернення Д. Лагірі до жіночих образів дозволяє глибше дослідити життєві та художні інтенції письменниці, зокрема, іiі погляди на жінку як самостійну людську особистість. Образи героїнь дуже схожі, проте у кожної своя життєва драма, породжена як внутрішніми (особисті думки i переживання), так i зовнішніми (перебування в іншій країні) чинниками.

\section{СПИСОК ВИКОРИСТАНИХ ДЖЕРЕЛ}

Балей, 2002 - Балей С. 3 психології творчості Шевченка. Зібр. творів у 5 т. Т.1. ЛьвівОдеса. ІФЛУС ЛФС “Cogito", 2002. С. $174-210$.

Єфремов, 2007 - Сфремов С. Історія українського письменства. К.: Феміна, 1995. 688 c.

Кудрявцев, 2007 - Кудрявцев M. Своє і чуже: історико-літературознавчі та компаративістичні студії. Кривий Ріг: Видавничий дім, 2007. 368 с.

Матіос, 2005 - Maтіос М. Солодка Даруся. Львів: Літературна агенція «Піраміда», 2005. $176 \mathrm{c}$

Пискун, 2001 - Пискун Е. В. Мультикультурализм США и культура афроамериканцев (Т. Моррисон, Э. Уокер): дисс. ... канд. филос. н.: 24.00.01. М.: 2001. 179 c.

Тлостанова, 2010 - Тлостанова M. Множественная идентичность в контексте концепции транскультурации. Личность. Культура. Общество, 2010. Т.12. № 4. С. $142-156$ 
Clifford, 1997 - Clifford J. Routes: Travel and Translation in the Late Twentieth Century. Cambridge, MA: Harvard UP, 1997. P. 25-32.

Henley, 1992 - Henley A. Space for Herself: Nadine Gordimer's "A Sport of Nature" and Josephine Humphrey's "Rich in Love". Frontiers: A Journal of Women's Studies. No.13.1. 1992. P. 81-89.

Lahiri, 1999 - Lahiri J. Interpreter of Maladies. Boston, New York: Houghton Mifflin Company, 1999. 198 p.

Raj, 2016 - Raj S.A. Cultural Alienation in Jhumpa Lahiri's Short Stories Interpreter of Maladies. International Journal of English Language, Literature and Humanities, Volume 4, Issue 1. January 2016. P. 459-470.

Trinh, 1994 - Trinh T.M. Other than My Self/My Other Self. Travellers' Tales: Narratives of Home and Displacement. Eds. Robertson G. et al. London: Routledge, 1994. P. 15-34.

\section{REFERENCES}

Baley, 2002 - Baley S. (2002). Z psihologii tvorchosti Shevchenka [On the psychology of Shevchenko`s writing]. Zibr. tvoriv u 5t. T.1. Lviv-Odesa. IFLUS LFS "Cogito, P. 174-210 [in Ukrainian]

Efremov, 1995 - Efremov S. (1995). Istoria ukrainskogo pusmenstva [History of Ukrainian Writing]. Kyiv. Femina, 688 p [in Ukrainian].

Kudryavtcev, 2007 - Kudryavtcev M. (2007). Svoje i chuzhe: istoryko-literaturoznavchi ta komparatyvistychni studii [Our and other: historical and literary and comparative studies]. Krivoy Rog: Vydavnychyj dim, 368 p [in Ukrainian].

Matios, 2005 - Matios M. (2005). Solodka Darusya [Sweet Darusya]. Lviv: Literaturna agencija "Piramida", $176 \mathrm{p}$ [in Ukrainian].

Pyskyn, 2001 - Pyskyn E.V. (2001). Multykuralizm SShA i kultura afroamerikancev (T. Morrison, Je. Uoker) [Multiculturalism of the United States and African Americans` culture (T. Morrison, A. Walker)]: diss. ... kand. filos. n.: 24.00.01. Moscov. 179 p [in Russian].

Tlostanova, 2010 - Tlostanova M. (2010). Mnozhestvennaya identichnost` v kontekste koncepcii transkulturacii [Multiple identity in the context of transculture concept]. Lichnost'. Kultura. Obshhestvo. T.12. \#4. P. 142-156 [in Russian].

Clifford, 1997 - Clifford J. Routes: Travel and Translation in the Late Twentieth Century. Cambridge, MA: Harvard UP, 1997. P. 25-32.

Henley, 1992 - Henley A. Space for Herself: Nadine Gordimer's "A Sport of Nature” and Josephine Humphrey's "Rich in Love". Frontiers: A Journal of Women's Studies. No.13.1. 1992. P. 81-89.

Lahiri, 1999 - Lahiri J. Interpreter of Maladies. Boston, New York: Houghton Mifflin Company, 1999. 198 p.

Raj, 2016 - Raj S.A. Cultural Alienation in Jhumpa Lahiri's Short Stories Interpreter of Maladies. International Journal of English Language, Literature and Humanities, Volume 4, Issue 1. January 2016. P. 459-470.

Trinh, 1994 - Trinh T.M. Other than My Self/My Other Self. Travellers' Tales: Narratives of Home and Displacement. Eds. Robertson G. et al. London: Routledge, 1994. P. 15-34. 
